Yu. Pylypenko ${ }^{1}$, Dr. Sc. (Econ.), Prof., orcid.org/0000-0002-4772-1492,

H. Pylypenko' ${ }^{1}$, Dr. Sc. (Econ.), Prof., orcid.org/0000-0003-2091-4320,

N. Lytvynenko ${ }^{1}$, Dr. Sc. (Econ.), Assoc. Prof., orcid.org/0000-0003-3797-8398,

O. Tryfonova1, Dr. Sc. (Econ.), Assoc. Prof., orcid.org/0000-0003-2283-6258,

E. Prushkivska ${ }^{2}$, Dr. Sc. (Econ.), Prof., orcid.org/0000-0002-4227-8305

\title{
PATHWAY OF THE INSTITUTIONAL DEVELOPMENT: PRACTICE OF LIBERAL TRANSFORMATION IN UKRAINE AND BELARUS
}

Purpose. To identify specific features of the mechanism of institutional changes in the countries of post-socialist transformation and to determine the effect of informal norms upon the pathway of institutional development in Ukraine and Belarus.

Methodology. Theoretical and methodological basis of the research is represented by theoretical synthesis of non-institutional and traditional versions of the idea of institutional changes expressing the concepts of spontaneity and premeditation as for selecting the institutions depending upon economic, political, and sociocultural conditions of the national economy development. Quantitative evaluation of the effect of culture upon the pathway of institutional development in Ukraine and Belarus was performed basing upon the Values Survey Module 2008 methodology proposed by G. Hofstede. Comparison of the tendencies and results of liberal transformation in post-socialist countries was based on the logical and historical method.

Findings. It has been demonstrated that the pathway of institutional changes in any society is determined by spontaneous processes and means a conscious choice of the development course through the establishment of principally new institutions and/or their borrowing from other more progressive systems. Restricted nature of the dominating ideas concerning the completeness of institutional reforms at certain historical stage by means of establishing stable relations between the borrowed institutions and proper institutional environment has been shown. Analysis of the practice of liberal transformation in Ukraine and Belarus has been used to prove the possibility of achieving a high level of adaptation of a new institution to the available informal norms in the context of general inefficient pathway of the institutional development.

Originality. For the first time, qualitative evaluation of the internal constituents by means of value indicators by G. Hofstede has been applied to describe informal norms of the institutional environment in Ukraine and Belarus characterizing the Path Dependence effect. The obtained data have made it possible to define the degree of inconsistency between formal and informal institutions of transformational economy. Effect of blocking in the development of the Ukrainian economy has been identified; the effect is observed in the context of a repeated situation when balanced but inefficient norms are self-supported in the institutional environment of the country decelerating its development.

Practical value. Scientific ideas concerning the mechanism of institutional changes, proposed approaches to evaluate informal institutions, and determination of the level of their consistency with formal rules can be the basis for more efficient control of the process of institutional changes.

Keywords: formal and informal institutions, institutional changes, institutional trap, post-socialist transformation, liberal reforms, indicators by G. Hofstede, Ukraine, Belarus

Introduction. Nowadays, more than two decades after gaining the independence, Ukraine is trying to create the conditions, required for liberal development of its economy, and approbating practically the positive experience of the functioning of market institutions demonstrated by the developed countries worldwide. Years of reforms, being unsuccessful, have demonstrated that in the majority of cases, the processes go without any support from the latest advances in economic sciences demonstrating spontaneous nature. The facts are clear: in the late 1990s, about thirty countries began their reforms aimed at replacing centralized and planned economy with the liberal model. First, that was the shock liberalization according to the scenario of the Washington Consensus, breakage of administrative system, and plunge into the unfettered market forces. Later, there came the understanding of the idea that free market and fair business do not appear naturally but require long-term historical progress and hard work to create certain institutional conditions for the effective functioning. However, considering current results of transformational processes in post-socialism Europe, we can see the unequal economic and institutional development in certain countries being the result of different starting conditions for

(C) Pylypenko Yu., Pylypenko H., Lytvynenko N., Tryfonova O., Prushkivska E., 2019 liberal transformation. Due to that fact, scientists face a number of rather complicated questions as for the following: how to adapt international experience to the national conditions and provide efficient functioning of new economic and political institutions.

Literature review. Problems of institutional transformation became of special importance within the period when problems of the post-socialist countries transition to market economy came to light. Scientific studies aimed at the detecting of the reasons of the Washington Consensus failure and searching for mechanisms of the efficient market economy became active in all the former USSR. Among the studies of that period, institutional theory, whose representatives tried to draw attention to the dependence of social transformations upon the specific features of institutional environment (Dementiev, 2012; Kirdina, 2000; Nureiev, 2009; Oleinik, 2000; Polterovich, 2007; Tambovtsev, 2010 and others), was the most prominent one.

Unfortunately, in all the former USSR, acceptance of the need in consideration of historical traditions and informal institutions based on them has not been scientifically substantiated; this substantiation would make it possible to develop a theoretical model and apply it in practice. Mostly, scientific literature demonstrates interest in the chapters of history of the country's development, which, according to the authors, 
proves compliance or incompliance of the available informal institutions with those structures being implemented in economic and political space in the process of institutional reforms. However, in all importance of such an approach, it does not allow determining and evaluating quantitatively the dominating informal institutions of modern Ukrainian society and, correspondingly, considering their essential characteristics while developing strategy of the institutional progress in the country. Alternatively, in terms of the Western studies, quantitative methods to describe institutions and establishment of relations between them, have become the priority being the basis to make conclusions on their effect upon the development.

In this context, papers by R. Markowski (studying problems of democracy and market economy in the countries of central and Eastern Europe due to the imperfect institutions being the post-Soviet heritage) and M. Dabrowski (determining peculiarities of interrelation between economic and political freedom in post-communist countries as a result of the effect of social economy institutions [2]) are rather representative ones. Similar tendencies are characteristic for papers by L. Uberti (studying a phenomenon of corruption in the countries with transient economy [3]), M. Berki (considering problems of the development of Eastern European cities and towns depending upon the conditions of socialistic development [4]), M. Jackson and G. Evans (researching processes of social mobility in post-socialist European countries [5]) and others. It appears that such an approach is the reason for the fact that the theoretical results are of more pragmatic nature, which helps to demonstrate in more detail the effect of institutions of the past upon the present period.

Purpose. The purpose of the article is to explain the specific features of the mechanism of institutional changes in the post-socialist transformation countries and to determine the effect of informal norms upon the pathway of institutional development in Ukraine and Belarus.

Results. In terms of the available studies of institutional changes, researchers share several opinions originating from different understanding of the nature of institutions. Representatives of neo-institutionalism rely upon neoclassic ideas as for economic activity of the players considering it to be rational. In terms of such an approach, it is stated that social norms are not specified from outside as the norms of behaviour, but they are the result of conscious choice. A player acting rationally chooses the variant of following the norms and rules; while adopting them, a player saves efforts for implementing the optimizing behaviour. Striving to carry into effect their own economic interest in the process of some activity, the players elaborate certain rules determining the access to the limited resources and mechanisms of income acquisition. The rules are based on the institution of private property which forms clear impetuses for economic activity and its limitations. Hence, people's behaviour becomes predictable and determined facilitating interaction and forming consistent expectations in terms of minimum information exchange.

Mechanism of institutional changes within the neo-institutional theory was developed by D. North $(1981,1990,1991)$ who considered them to be the source of shifts in the structure of relative prices caused by new knowledge, technologies, and ideology. On the one hand, those shifts represented as changes in the income of production owners result in the necessity to send resources for the implementation of new profitable opportunities; on the other hand, the shifts are to try to replace distribution rules. The result depends upon the fact whether current rules allow maximizing the profit. If the available institutional conditions (first of all, property right and dominating ideology) deteriorate economic situation of the players, they will strive to form new rules and, respectively, new conditions of the wealth distribution. Regrouping of the property rights and changes in the directions of ideological effect upon people's consciousness to rationalize standards of the behaviour always take place in terms of the available transaction costs. Thus, only those institutions that provide optimal ratio between transaction costs and benefits of labour distribution and exchange, i. e. forming the most favourable conditions for economic growth, may survive historically.

Representatives of the traditional institutionalism express another idea as for the mechanism of institutional changes. The scientists consider that people's behaviour in the economic sphere is determined not only by valuable consideration but also by dependence upon the habits and traditions stipulated by sociocultural values which are handed down from generation to generation by means of culture. Striving to meet the needs, people created such conditions for their own living which ensured their preserving as a biological species. In the course of time, those habits and rules being the most efficient in preserving life-sustaining activity of large groups of people have resulted in the formation of behavioural stereotypes and establishment of corresponding institutions. The latter form the structure of future coordinated actions and create incentives for their implementation.

Thus, from the viewpoint of traditional institutionalism, the players making up the society are already given institutional formations in the form of certain rules regulating economic relations. They are also provided with specific methods to follow and support those rules. It means that any economic activity is implemented within the available institutional constraints which both limit and stimulate human activity. Theory of constitutional changes, proposed by T. Veblen, a founder of the traditional institutionalism, assumes that the individuals have certain possibility to effect actively the institutional environment resulting in the fact that institutions and individuals are interconnected. According to T.Veblen, "Each personality who is required to change his/her way of life and habitual relations with the surrounding people will feel inconsistency between the way of life being dictated him/her by new needs and traditional ones which he/she got used to. Being in situation like that, people get the most active impetus to rebuild their habitual lifestyle and adopt readily new living standards" [6]. Thus, according to the concept of traditional school, economic activity takes place within the current institutions being a product of previous human actions. Those institutions favour the existence of the repeated practices and functions as the behavioural restrains. In the course of time, due to numerous needs, there are certain changes in the economic conditions of human activity; new forms of social and economic relations emerge being the basis for new institutional environment. In other words, there is a natural selection of the most adapted way of thinking and the process of enforced adaptation of the players to new conditions.

Since the way of thinking stipulated by sociocultural values and, correspondingly, institutions basing upon that thinking are the result of processes taking place in the past and adapted to the past circumstances, that is the most inertial social and psychological factor of the institutional development. P. Devid and B.Arthur, founders of the Path Dependence theory (dependence upon the previous development), pay special attention to this fact, emphasizing that informal norms, being the expression of standard conceptual frameworks of the representatives of certain culture, have the tendency to continue its existence for a long time being not subject to conscious willingness to changes (Devid, 1985, 1986), (Arthur, 1990).

Thus, neo-constitutional theory stresses the conscious choice of the institutions and leading role of legislative and ideological innovations as well as property rights which change transaction costs with the following effect upon the selection of the development pathway. In terms of the traditional institutionalism, inertia stipulated by slow changes in the established way of thinking move to the forefront. In terms of the economic science, those ideas strengthened the realization of the fact that any changes in formal institutions (legal norms, laws, legal case) cannot take place without the consideration 
of informal rules (values, habits, thinking stereotypes, moral norms). If institutional development is of evolutional nature, then formal and informal institutions correlate as two successive stages of transformation: in the course of historical development, informal rules experience certain changes with their further formalization by stating in legal norms. Under such conditions, informal institutions coincide with formal ones not resulting in the increased transaction costs.

However, evolution pathway of the institutional changes is not always acceptable: first, due to slow rate of the transformation; second, due to possible inefficiency of the informal institutions themselves. In this context, there is the representative case of the historical experience of the establishment of market relations in the majority of European countries when key values of canonical Catholicism were the ideological barrier for the development of private initiative and desire to implement their own valuable considerations resulting in the conservation of inefficient forms of production and exchange. It is clear that one could not expect the establishment of the economic model in those countries without the Reformation movement aimed at cardinal changing of the dominating religious systems (Weber, 1958). Owing to that fact, individuals choose progressively not the way of adaptation to slow evolution transformations in the institutional environment but its change by means of reforms. Essence of the latter is in the development (structuring) of principally new institutions and/or transplantation - borrowing of the institutions from other, as a rule, more developed systems (Tambovtsev, 1997; Oleinik, 2000; Polterovich, 2001, 2007).

Those were the borrowings of the efficient Western institutions to become the basis for liberal transformation of postsocialist countries in the 1990s. As it is known, ideological basis of the transformations during that period was laid by socalled Washington Consensus - collection of ten rules elaborated by the experts of the American government, World Bank, and International Monetary Fund according to which Latin American and Eastern European countries had to reform their economic systems to develop their markets and provide economic growth (Williamson, 1994). Stabilization, liberalization, and deregulation have become the "three pillars" of the reforms. In this context, privatization and relaxation of state authority concerning the economy as a required measure to form self-regulating market were considered to be the key tools of their implementation. Institutional conditions of the development of those countries and, first of all, specificity of their informal institutions were not taken into consideration at all. It was considered that all the post-socialism countries had to go along the similar institutional pathway - to form market institutions according to the Western European example.

Outcomes of the first years of the Washington Consensus implementation are well-known: all the post-socialism countries which followed its recommendations demonstrated immediate economic recession, intensified inflation, increased unemployment, internal and external debts. According to V. Polterovich, basing upon the results of 10 years of liberal transformation, only five countries - Albania, Hungary, Poland, Slovakia, and Slovenia - have managed to increment GDP level. Other countries, especially, post-Soviet ones, have experienced shock decrease: by 2000, Latvia has lost $26 \%$ of GDP, Lithuania $-35 \%$, Russia $-38 \%$, and Ukraine $-58 \%$. In this context, only three post-Soviet republics - Uzbekistan, Turkmenistan, and Belarus - have had the least negative effects due to the reforms "from the top" owing to the slow rate of the reforms (Polterovich, 2007). Majority of the countries with transient economies, including Ukraine, have not managed to restore their economies yet.

Despite the fact that the reasons of that situation have already been identified theoretically - underestimation of the initial conditions, role of the government, and features of the institutional environment (L. Balcerowicz, 1995; J. Kornai, 1994; L.Clay, 1996; Rodrik, 1996; Roland, 2000; Stiglitz, 1998; Przeworski, 2000 and others), - hurdles of the development in certain post-Soviet countries have not been cleared yet. Such situation stipulates the necessity of more thorough studies aimed at the identification of the specific features of the mechanism of institutional changes in the countries having experienced post-socialism transformation.

Theoretical synthesis of neo-institutional and traditional versions of the institutionalism, within which the institutions dynamics is as the unidirectional result of the conscious choice and spontaneity, is selected as the methodological basis for the scientific inquiry. Culturological factors characterizing dominating informal institutions hold a prominent position in that synthesis. Such an approach makes it possible to demonstrate how the available social informal rules are adapted to the formal institutions provided during the implementation of reforms. We consider that such research should be carried out on the basis of comparative analysis of two countries which will help demonstrate different scenarios of their institutional development depending upon the Path Dependence effect.

To compare, consider Ukraine being harmed the most during the transformations by means of "shock therapy", and Belarus, which appeared to be the country of more moderate reforms and their less damaging outcomes respectively. First, concentrate on the analysis of the starting conditions being the economic prerequisites according to the opinion of the most researchers. Basing upon the statistical data of 1990, i.e. the period of the reforms beginning, we can state that the starting conditions of market transformations in Ukraine and Belarus had both similarities and differences. According to the data from Table 1, there are certain available structural differences of the industrial potential of those two countries as for the national ratio of mining and processing industries.

Contrary to Belarus, in Ukrainian production, mining industries (first of all coal and iron-ore ones) cover the largest share. Moreover, while analysing the structure of the processing industry, it is clear that national production was overburdened with heavy industries - fuel and energy complex and ferrous metallurgy (19.9\% as opposed to $8.1 \%$ in Belarus). Considerable share of consumer industry in Belarus (17.2\%)

Table 1

Share of the products by certain industries in total amount of the industrial production of Belarus and Ukraine at the beginning of reforms [7-9]

\begin{tabular}{|c|c|c|c|c|c|c|c|c|c|c|c|c|}
\hline & \multirow[b]{2}{*}{$\stackrel{\stackrel{0}{\Xi}}{\stackrel{\Xi}{\Xi}}$} & \multirow[b]{2}{*}{ 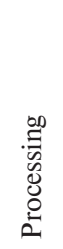 } & \multicolumn{10}{|c|}{ Industries } \\
\hline & & & 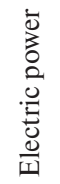 & 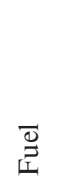 & 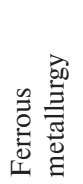 & 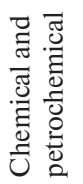 & 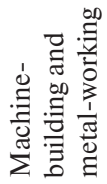 & 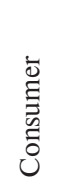 & 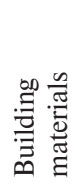 & $\begin{array}{l}\overline{8} \\
\end{array}$ & 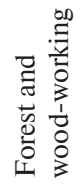 & 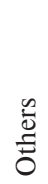 \\
\hline Ukraine & 4.3 & 95.7 & 3.2 & 5.7 & 11.0 & 6.0 & 30.7 & 10.8 & 3.4 & 22.6 & 2.9 & 3.7 \\
\hline Belarus & 2.1 & 97.9 & 2.6 & 4.6 & 0.9 & 9.0 & 34.2 & 17.2 & 3.7 & 14.9 & 4.4 & 8.5 \\
\hline
\end{tabular}


comparing to Ukraine $(10.8 \%)$ and greater share of food industry in Ukraine (22.6\%) than in Belarus (14.9\%) had significant structural differences in the industrial potential of the countries. At the same time, basing upon the represented structural characteristics, their starting positions in the industries of building materials, forest and wood-working as well as machine-building ones are almost similar. However, in terms of the latter one, Ukraine demonstrated major share of the military and industrial complex. The countries did not differ much as for the characteristics of labour potential as well as in terms of the agriculture. Domination of large-scale enterprises based on the government ownership was one more similar fact for the countries under analysis; those enterprises were mostly monopolies in their organization and legal status.

All those facts emphasize that there are only minor differences in the structure of Ukrainian and Belarusian industries at the beginning of their market reformation. Thus, we believe that despite the fact that the starting economic conditions in Ukraine and Belarus had certain effect upon the scale and character of market transformations, they were not critical from the viewpoint of their implementation efficiency - first years of reforms had practically the same outcomes for both Ukraine and Belarus. Situation changed dramatically during the further period where those countries chose principally different paths of institutional changes. We consider that it is different degree of compliance of economic and institutional transformations in Ukraine and Belarus implemented in the process of market reformation, which is the main reason for their rather diverse further social and economic development.

From the theoretical viewpoint, success of institutional reforms depends directly upon the fact how formal institutions borrowed from other economic systems have managed to be integrated into the current institutional environment. First of all, that concerns their compliance with the informal norms and rules. The latter, originating from the culture, form a peculiar kind of "freedom corridor" for adaptation of the formal institutions. Establishment of that corridor for each specific national economy should be determined and evaluated quantitatively - with the help of statistical and empirical data. We propose to solve that problem involving the parameters expressing values of the population in terms of indicators by G. Hofstede (Hofstede, 1980，1994，2001). In terms of Ukraine, the data were obtained during the nationwide inquiry performed by the authors of this paper in 2009-2010 within the frameworks of scientific and research project "Economic consciousness of the Ukrainian society during the transformational changes" (state registration number is 0110U005381) $[10,11]$. Our colleagues from Belarus State Economic University (Minsk), who carried out similar study in 2009-2015 in Belarus [12], provided the data concerning Belarus. Ukrainian sampling contained 2058 people (44\% - men, $56 \%$ - women); Belarusian sampling covered 252 people $(54.37 \%-$ men, $45.63 \%-$ women). The respondents of both countries differed in their education, age, social status, profession, and confession; they were mostly residents of regional and district centres. The inquiry was based on VSM 08 methodology by $\mathrm{G}$. Hofstede with the following calculation of seven valuebased indicators [13] represented in Table 2.

Power Distance (PDI) and Individualism (IDV) indices are the most representative ones demonstrating how people are ready to embrace liberal values. The first index evaluates willingness of the population to accept unequal distribution of power in the institutions and organizations; it characterizes the degree at which representatives of different cultures create and support differences in the status and power among the interworking individuals. Cultures with high PDI value produce actively rules, mechanisms, rituals to support and strengthen hierarchical relations among the members of the society. That is the nonstandard evaluation of authoritarianism - where there is a great distance between people and power, the power itself is considered as the most important part of life; more-
Table 2

Values of G. Hofstede VSM 08 for Ukraine and Belarus [10, 12]

\begin{tabular}{|c|c|c|c|c|c|}
\hline & 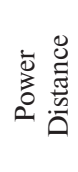 & 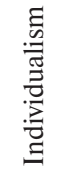 & 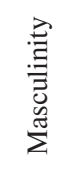 & 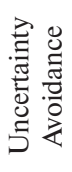 & 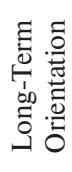 \\
\hline & PDI & IDV & MAS & UAI & LTO \\
\hline Ukraine & 22.79 & 31.49 & -8.67 & 4.81 & 4.08 \\
\hline Belarus & 44.0 & 31.5 & 5.25 & 6.6 & 15.5 \\
\hline
\end{tabular}

over, emphasis is put on the coercive power. Cultures with low PDI index show certain ignoring of the power differentiation, i.e. competence of power, respect for the individual and equality are considered to be more important.

The second index evaluates the following: to what extent individualistic tendencies are supported in the society as opposed to the group or collectivistic ones. Cultures with the prevailing individualistic tendencies consider that needs, desires, and interests of an individual are more important than the group or collective ones. In terms of such society, individuals tend to take care of themselves and their own families. On the contrary, collectivistic cultures approve the values meaning sacrifice of individual interests for the public good. Under such conditions, individuals tend to unite themselves into certain groups being responsible for a personality in turn for his/ her loyalty.

According to current surveys, countries with the developed market economy (most countries of the European Union and the USA) usually have low PDI and very high IDV indices. Ukraine demonstrates combination of low power distance (22.79) and low individualism (31.49). Such a combination is rather specific. If it is applied to the explanation of economic interactions, we will have rather low tendency of the population to accept a government form of coordination along with quite low tendency to accept a market one. Generally, in any society, one of the two coordination mechanisms prevails: either economic relations are regulated by the government, which is legitimate owing to the consensus of values, or those relations are mostly subject to market self-regulation. In our case, neither market, nor government is the institution able to support efficiently economic order in the Ukrainian society.

Such situation is related to the historical traditions: lacking their own state system and evolving as a part of other countries for a long time, the Ukrainians have elaborated stable stereotype of disregarding any power. At the same time, Ukrainian collective economic consciousness is characterized by the phenomenon of ambivalence - parallel orientation to the mutually exclusive values and norms. According to the studies (Magun, Rudnev, 2007; Pylypenko, 2012), even given the nihilism of the Ukrainians to the supreme power, in terms of their psychological orientation, they are notable for power control, domination over people and resources; they are also prone to struggle for power if it is possible to gain benefit from it. Belarus does not demonstrate considerable contradictions - its population is highly prone to government coordination $(P D I=44.0)$ correlating to low individualism $(I D V=$ $=31.5$ ). In other words, the Belarusians are representatives of more collectivistic culture than individualistic one; thus, they tend to accept mostly governmental forms for the economic activity effect.

The identified dependences explain why liberal reforms in Ukraine and Belarus have had similar outcomes. Both countries started their transition to the market economy with the implementation of "shock therapy" - accelerated liberalization of social relations by means of rapid privatization (mostly, not in the monetary form), removing restrictions in the sphere of pricing and capital movement, sharp reduction of the vol- 
umes of government costs, and decreased level of the social programme financing. On the one hand, those changes of formal economic institutions have resulted in the aggravation of crisis phenomena and escalation of social and economic contradictions; on the other hand, that has factored into the legalization of informal norms and rules of behaviour existing in the rudimentary form during the period of the Soviet economy.

Owing to its natural-geographic and demographic factor, during the Soviet period, Ukraine formed powerful industrial fuel and energy complex, metallurgy, heavy industry and military industry, which played an important role in the labour distribution in the USSR; consequently, economic interest of the Ukrainian business sector elite and representatives of the security agencies appeared to be the most influential ones. That is confirmed by the fact that considerable share of the officials in the central administration of the USSR was from Ukraine, i. e. from Dnipropetrovsk and Donetsk regions. Ambivalence of the value-based attitude of the Ukrainians to the authorities has determined specific features of the behaviour of national party and economic bosses. During the first stage of privatization (1987-1992), directors of large industrial enterprises accumulated the most attractive state-owned objects that facilitated fast enrichment of those who controlled them in reality by means of the administrative functions. Since as far back as the Soviet time, those objects became the basis for the formation of special-interest groups of the close-network type, which included close friends and relatives, they favoured gradual merging of power and business.

The second stage (1992-September 1996) intensified further the tendencies resulted in the formation of certain influential financial and industrial groups reconstructing completely clannish nature of the Soviet-type power in the political system of Ukraine. Institutional environment formed like that developed in the way that the rules of game corresponding to this form of coordination began squeezing out gradually the institution of the available state influence as well as the elements of the market which started their implementation into the economy during the liberal reformation. That is why, attempts of the state to form wide range of private owners by means of wide-scale certificate privatization to develop competitive environment during the third stage of the reforms (1996-1998) was not successful. Within that period, legalization of previously accumulated capital was observed along with the strengthening of clannish-oligarchic economic system. As we can see, process of institutional development in Ukraine met all the dominating values of the country's population expressed by simultaneous low indices of the power distance and individualism as well as high value-based power orientation. During the transformational changes, dependence upon the previous development was shown in the fact that inefficient informal institutions of the past squeezed out new progressive norms and rules arising during the reforms.

Like in Ukraine, in Belarus, during the stage of the nomenclative privatization, there is a process of transformation of the impersonal state-owned property into the individual one. Transferring of the property to the enterprises on the basis of complete economic handing over (directors invest their shares into the newly established enterprises from the funds of state-owned property objects) and wide-scale starting of cooperatives and leasing firms based on the state enterprises were the mechanism of that process. On the one hand, that expanded considerably the enterprise rights in terms of pricing, distribution of manufactured products and income; on the other hand, that facilitated initial accumulation of the capital by the bureaucracy. The processes continued during the second stage (mass privatization and development of the system of legal private property).

At first view, such tendencies in the development of property relations are rather similar to the Ukrainian realia of that time. However, it should be taken into consideration that party elite in Belarus was not so numerous among the representatives of the USSR central authorities comparing to Ukraine. Thus, consolidation of the newly arisen private capital in the bureaucracy hands was not a factor of "privatization" of the proper state by the special-interest groups. In terms of the Belarusian society, the state continued to be strong being able to influence the reforms. In addition, that fact is confirmed by the informal norms - according to the PDI index, the Belarusians are more tolerant than the Ukrainians in the acceptance of the prerogative of the centre to make decisions concerning essential spheres of the people's life; they also consider their passive attitude or inactive participation in making governmental decisions to be rather admittable.

The abovementioned factors favoured the fact during the third stage of the reforms, the state stops wide-scale privatization, prohibits selling the share bought by the members of labour collective on a preferential basis. Moreover, the state began controlling the property; status of the unitary enterprise was implemented. To strengthen the control for stock companies established on the basis of state-owned property, so-called "golden share" was introduced. Further, privatization in Belarus took place under the strict governmental control aimed at the support of private capital in the sphere of small and medium business activities in terms of the preserved functionality of large enterprises in the state sector of the economy.

In this context, the state refused from the removal of large kolkhoz and sovkhoz production in the agricultural economy of the country; it began certain reforms towards the formation of competitive environment by supporting farmers in case of their efficient activities. Sharp changes in the course of liberal reforms meant that Belarus entered the pathway of evolutionary variant of institutional changes according to which administrative institutions were transformed slowly and smoothly according to the available informal norms. In 1997, correct course of the selected strategy became clear: for the first time during the years of reforms, Belarus GDP began increasing while in Ukraine it continued its dramatic decrease. Comparing to the growth of social standards in Belarus supported by the budgetary financing, welfare of the ordinary Ukrainians was reducing dramatically along with the fantastic growth of the wealth of so-called "new Ukrainians".

Other indicators by G. Hofstede illustrate the effect of the informal institutions upon the transformational processes as well. According to the Uncertainty Avoidance (UAI) index, demonstrating tendency of the population to follow strictly formalized rules as the method to avoid uncertain, unclear, and inexplicable situations, Ukraine and Belarus have low values (4.81 and 6.6 respectively) comparing to the developed countries. However, that index in Belarus is a little higher than in Ukraine. It means that the Belarusians are more oriented towards the certainty and predictability than the Ukrainians. Personal protection is more important for them than freedom; thus, they prefer strong authorities able to secure social quietude and order in the country. On the contrary, the Ukrainians are oriented to the freedom archaically, being characterized by high level of excitability and emotionality as well as the ability to break the rules from the pragmatic consideration.

The Long-Term Orientation (LTO) index, demonstrating ability of the society to overcome anxiety and stress due to the situations connected with uncertainty, is in complete compliance with the Uncertainty Avoidance index. High level of that index shows the fact that the society demonstrates pragmatism and strategic orientation to the future rather than traditionalism and short-term tactic orientation. According to that parameter, the Belarusians demonstrate higher long-term orientation comparing to the Ukrainians ( 15.5 and 4.8 respectively). That has certain effect on the economic behaviour of the players: under conditions of total redistribution of the property, value-based dominant of the Ukrainians to live for today has 
become a fatal one for the economic development. In terms of Belarus, economic contacts were being constantly restored after the "shock therapy" while in Ukraine new authority figures were just destroying the industrial potential of the enterprises under their control in order to get momentary profit - they sold equipment in the external markets at the price of metal scrap, dismounted permanent structures to get cheap building materials etc. As a result, rent-oriented behaviour of the business sector has become a prevailing one being still dominating in the Ukrainian society.

Ukrainian culture, being mostly feministic, did not also favour the establishment of market principles in that country. According to the Masculinity (MAS) index representing people's propensity to the insistence and cruelty, focus on the material success, egoism and competitiveness (entrepreneurial risks), the Ukrainians have more tendency to solidarity, cooperation, taking care of the weak, maintaining personal relations, and less orientation to success. On the one hand, such values do not facilitate the development of business in its classic variant; on the other hand, they help to develop the business basing upon the principles of partnership and collaboration. Low masculinity has become the factor favouring wide spreading of so-called network coordination - domination of customized connections and customer relationship at every level of the economy functioning.

Conclusions. Comparative analysis of the outcomes of the economy liberalization in Ukraine and Belarus in the 1990s has demonstrated the importance of the consideration of the fact that the country depends upon the previous pathway of its development and the necessity to form institutional environment from the viewpoint of the dominating informal institutions. Implementation of that task requires quantitative estimation of the latter. However, current economic science has not elaborated universal approaches to the quantitative estimation of the qualitative characteristics of the institutions yet. Taking into account the fact that sociocultural values, being the basis for the formation of behaviour stereotypes, are the basis for the informal rules, we consider it expedient to evaluate them by means of the methodologies being rather popular in terms of the cross-cultural analysis.

Degree of the consistency between formal and informal institutions is considered as the completeness criteria of the institutional reforms while determining historical and sociocultural conditions. In this context, attention should be paid to the fact that the effect of historical dependence of the development is not always positive. Practice of the Ukrainian liberal reforms is the sharp evidence of such dependence. Simultaneous low indices of the power distance and individualism along with the ambivalent value-based orientations (general liberal mindset in terms of the desire to preserve certain bureaucracy positions) peculiar for the population have become the basis for the formation and functioning of informal rules which have established national bureaucratic type of coordination in the form of clannish-oligarchic capitalism. Lack of consideration for the specificity of dominating informal institutions of the Ukrainian society at the beginning of reforms has resulted in deep transformational recession stipulated by the Path Dependence effect.

That effect has acted as a certain barrier for the development - the situation when balanced but inefficient norms are stable and able for self-support (institutional trap). Under such conditions, it appears that the economic system follows inefficient pathway of its development; changes in this pathway depend upon the fact whether the inefficient informal norms could be legalized in other institutional forms being more favourable for their development. Practice of the analysed Belarusian reforms is a good example of gradual bringing of the formal norms into compliance with the available informal institutions. Besides, that is the way for implementing reforms in other post-socialist countries. For instance, in China, whose current rapid economic growth is just stunning, planned econ- omy was being "washed out" evolutionally and smoothly: first, there was permission to establish the limited number of nonstate enterprises; further, there was a transition to the controlled market under conditions of planned economy; finally, the controlled market was a basic mechanism of socialistic economy. The fact of replacing the old institutional forms with the new ones only after the proved efficiency of the latter was the key moment of the Chinese economy liberalization. In this context, ideological policy aimed at the changes in the mentality of the Chinese population was being implemented actively (C. Hermann-Pillath, 1994). Those institutional and behavioural changes were coordinating gradually both formal and informal institutions modifying the development pathway. The practice of other post-socialist countries also demonstrates that the evolvement of market economy was always effected by considerable influence of the state, which formed certain rules of game, created favourable institutional environment, and, what is rather important, developed effective enforcement mechanisms for the observance of the newly-introduced rules.

Thus, scientific concept of the regularities of the institutional changes as well as understanding of their dependence upon the historical and cultural conditions of the development of a certain country forms the basis for the desired direction of the social development. Under conditions of modern Ukraine, basic formal institutions continue their functioning on the model of inefficient informal norms losing its universality, automaticity, and transparency. Consequently, any laws and governmental orders come into effect only when they are of certain benefit for the groups interested in them. Such configuration of the institutional space is rather inefficient requiring certain changes. The problem is in the fact that in terms of Ukraine, the state cannot implement and maintain new formal rules since they constitute direct threat to the ruling elite whose interests collide with the market principles of the economy functioning.

We believe that the way out from that institutional trap may be represented only by gradual transition to other forms of social coordination; in terms of the Ukrainian society, network coordination is the key one. According to the available practice, in current Ukraine, poor prestige of the state favours active development of the economic self-administration at the local level and establishment of the institutions of civil society ("bottom-top reforms"). Those processes mirror the tendency to formalize the available informal norms when customer and clannish relations in the economy and society are implemented not in the supreme power establishments but at the local level (local self-administration). Whatever imperfect the norms are from the viewpoint of the classic market ideas, their gradual formalization with the following modernization will allow Ukraine to overcome the Pass Dependence effect which prevents it from entering upon the pathway of the efficient social and economic development.

\section{Reference.}

1. Markowski, R. (2017). Transformation experiences in Central and Eastern Europe. Retrieved from http://library.fes.de/pdffiles/id-moe/13169.pdf.

2. Dabrowski, M. (n.d.). Are economic and political freedoms interrelated? Retrieved from https://publications.hse.ru/mirror/pubs/share/direct/228353785.

3. Uberti, L.J. (2018). Corruption in Transition Economies: Socialist, Ottoman or Structural? Economic Systems, 42(4), 533-555.

4. Berki, M. (2014). Return to the road of capitalism: Recapitulating the post-socialist urban transition. Hungarian Geographical Bulletin, 3(63), 319-334.

5. Jackson, M. (2017). Rebuilding Walls: Market Transition and Social Mobility in the Post-Socialist Societies of Europe. Sociological Science, 4, 54-79.

6. Veblen, T. (2016). Theory of the idle class. Moscow: Lenand. 
7. Demographic Yearbook of the Republic of Belarus: statistical compilation (2014). Minsk: National Statistical Committee of the Republic of Belarus.

8. Macroeconomic research. Economy of Ukraine, 1990-2016 (n.d.). Retrieved from http://be5.biz/makroekonomika/profile/ua.html.

9. Macroeconomic research. Economy of Belarus, 1990-2016 (n.d.). Retrieved from http://be5.biz/makroekonomika/profile/ua.html.

10. Pilipenko, H. M., \& Litvinenko, N. I. (2015). Ukrainian Mentality in the Coordinates of the G. Hofstede Research Program. Ekonomichnyi Visnyk Natsionalnoho Hirnychoho Universytetu, 2, 14-22.

11. Pylypenko, H. (2017). Socio-cultural factors of economic development. Dnipro: NMU.

12. Ksenzova, V. E., Ksenzov, S. V., \& Krizhanovskaya, E. V. (2015). Features of the Belarusian mentality. Ekonomichnyi Visnyk Natsionalnoho Hirnychoho Universytetu, 2, 22-31.

13. Hofstede, G., Minkov, M., \& Vinken, H. Values Survey Module 2008 (VSM 08). Retrieved from http://www.geerthofstede.nl/research--vsm/vsm-08.aspx.

\section{Траєкторії інституціонального розвитку: досвід ліберальної трансформації в Україні та Білорусі}

Ю. І. Пилипенко ${ }^{1}$, Г. М. Пилипенко ${ }^{1}$, Н. І. Литвиненко ${ }^{1}$, О. В. Трифонова ${ }^{1}$, Е. В. Прушківська ${ }^{2}$

1 - Національний технічний університет „Дніпровська політехніка“, м. Дніпро, Україна, e-mail: pylypenkoYI@ gmail.com

2 - Запорізький національний технічний університет, м. Запоріжжя, Україна, e-mail: em.prushkovskaya@gmail. com

Мета. Розкриття специфіки дії механізму інституціональних змін у країнах постсоціалістичної трансформації, визначення впливу неформальних норм на траєкторії інституціонального розвитку України та Білорусі.

Методика. Теоретико-методологічним підгрунтям дослідження є теоретичний синтез неоінституціональної та традиційної версій концепції інституціональних змін, що відображає уявлення щодо спонтанності й навмисності вибору інститутів у залежності від економічних, політичних, соціокультурних умов розвитку національної економіки. Кількісна оцінка впливу культури на траєкторії інституціонального розвитку України та Білорусі здійснювалася за застосування методики Г.Хофстеда „Values Survey Module 2008“. Логіко-історичний метод був покладений в основу порівняння напрямів і результатів ліберальної трансформації в постсоціалістичних країнах.

Результати. Продемонстровано, що траєкторія інституціональних змін будь-якого суспільства визначається як спонтанними процесами, так і передбачає свідомий вибір шляху розвитку через конструювання принципово нових інститутів i/aбо їх запозичення 3 інших, більш передових систем. Показана обмеженість домінуючих уявлень про завершеність інституціональних реформ на певному історичному етапі встановленням стійких зв'язків між запозиченими інститутами та власним інституціональним середовищем. На основі аналізу досвіду ліберальної трансформації в Україні та Білорусі доведена можливість досягнення високого ступеня пристосованості нового інституту до існуючих неформальних норм при загальній неефективності траєкторії інституціонального розвитку. Окреслені напрями інституціональних змін в українському суспільстві.
Наукова новизна. Уперше для опису неформальних норм інституціонального середовища України та Білоруci, що характеризують ефект „залежності від попереднього розвитку“, застосована кількісна оцінка їх внутрішніх складових через ціннісні індикатори Г.Хофстеда. На основі отриманих даних встановлено ступінь неузгодженості формальних i неформальних інститутів трансформаційної економіки. Виявлено ефект блокування розвитку в українській економіці, що проявляе свою дію в постійному відтворенні ситуації, коли рівноважні, однак неефективні норми, самопідтримують своє існування в інституціональному середовищі країни i, тим самим, уповільнюють розвиток.

Практична значимість. Наукові уявлення про механізм інституціональних змін, запропоновані підходи до оцінки неформальних інститутів і визначення ступеня їх узгодженості із формальними правилами можуть виступати підгрунтям для більш ефективного управління процесом інституціональних змін.

Ключові слова: формальні і неформальні інститути, інституціональні зміни, інституціональна пастка, постсоціалістична трансформація, ліберальні реформи, індикатори Г. Хофстеда, Україна, Білорусь

\section{Траектории институционального развития: опыт либеральной трансформации в Украине и Беларуси}

Ю. И. Пилипенко ${ }^{1}$ А. Н. Пилипенко ${ }^{1}$ Н. И. Литвиненко ${ }^{1}$ Е.В.Трифонова 1 , Э.В. Прушковская ${ }^{2}$

1 - Национальный технический университет „Днепровская политехника“, г. Днепр, Украина, e-mail: pylypenkoYI@gmail.com

2 - Запорожский национальный технический университет, г. Запорожье, Украина, e-mail: em.prushkovskaya@ gmail.com

Цель. Раскрытие специфики действия механизма институциональных изменений в странах постсоциалистической трансформации, определение влияния неформальных норм на траектории институционального развития Украины и Беларуси.

Методика. Теоретико-методологическим основанием исследования является теоретический синтез неоинституциональной и традиционной версий концепции институциональных изменений, отражающий представление о спонтанности и преднамеренности выбора институтов в зависимости от экономических, политических, социокультурных условий развития национальной экономики. Количественная оценка влияния культуры на траектории институционального развития Украины и Беларуси осуществлялась через применение методики Г.Хофстеда „Values Survey Module 2008“. Логико-исторический метод был положен в основу сравнения направлений и результатов либеральной трансформации в постсоциалистических странах.

Результаты. Продемонстрировано, что траектория институциональных изменений любого общества определяется как спонтанными процессами, так и предусматривает сознательный выбор пути развития через конструирование принципиально новых институтов и/или их заимствование из других, более передовых систем. Показана ограниченность доминирующих представлений о завершенности институциональных реформ на определенном историческом этапе установлением устойчивых связей между заимствованными институтами и собственной институциональной средой. На основе анализа опыта либеральной трансформации в Украине и Беларуси доказана возможность достижения высокой 
степени приспособленности нового института к существующим неформальным нормам при общей неэффективности траектории институционального развития. Определены направления институциональных изменений в украинском обществе.

Научная новизна. Впервые для описания неформальных норм институциональной среды Украины и Беларуси, характеризующих эффект „зависимости от предшествующего развития“", применена количественная оценка их внутренних составляющих через ценностные индикаторы Г. Хофстеда. На основе полученных данных установлена степень несогласованности формальных и неформальных институтов трансформационной экономики. Обнаружен эффект блокирования развития в украинской экономике, проявляющий свое действие через постоянное воспроизведение ситуации, когда равновесные, однако неэффективные нормы, самоподдерживают свое существование в институциональной среде страны и, тем самым, замедляют развитие.

Практическая значимость. Научные представления о механизме институциональных изменений, предложенные подходы к оценке неформальных институтов и определения степени их согласованности с формальными правилами могут выступать основой для более эффективного управления процессом институциональных изменений.

Ключевые слова: формальные и неформальные институты, институциональные изменения, институциональная ловушка, постсоциалистическая трансформация, либеральные реформы, индикаторы Г.Хофстеда, Украина, Беларусь

Рекомендовано до публікації докт. екон. наук В. М. Шаповал. Дата надходження рукопису 13.05.18. 